\title{
Business Model Discovery by Technology Entrepreneurs Steven Muegge
}

\author{
"There is considerable evidence that business success") \\ depends as much on organizational innovation, for \\ example, design of business models, as it does on the \\ selection of physical technologies. \\ David Teece \\ Researcher, Consultant, and Professor
}

\begin{abstract}
Value creation and value capture are central to technology entrepreneurship. The ways in which a particular firm creates and captures value are the foundation of that firm's business model, which is an explanation of how the business delivers value to a set of customers at attractive profits. Despite the deep conceptual link between business models and technology entrepreneurship, little is known about the processes by which technology entrepreneurs produce successful business models. This article makes three contributions to partially address this knowledge gap. First, it argues that business model discovery by technology entrepreneurs can be, and often should be, disciplined by both intention and structure. Second, it provides a tool for disciplined business model discovery that includes an actionable process and a worksheet for describing a business model in a form that is both concise and explicit. Third, it shares preliminary results and lessons learned from six technology entrepreneurs applying a disciplined process to strengthen or reinvent the business models of their own nascent technology businesses.
\end{abstract}

\section{Introduction}

Strategy and innovation scholar Henry Chesbrough writes: "A business model has two important functions. It must create value within the value chain; and it must capture a piece of value for the focal firm in that chain" (Chesbrough et al., 2006; tinyurl.com/8x8byvv). Though debate continues among researchers and practitioners about precise operational definitions and rival classification schemes, consensus has gradually emerged that understanding how a particular firm creates and captures value is central to a full understanding of how and why that firm's revenues exceed its costs over time.

Value creation and value capture establish a deep connection between business models and technology entrepreneurship. In the February 2012 issue of the TIM Review, guest editor Tony Bailetti defined technology entrepreneurship as an investment in a project that as- sembles and deploys specialized individuals and heterogeneous assets that are intricately related to advances in scientific and technological knowledge for the purpose of creating and capturing value for a firm (Bailetti, 2012; timreview.ca/article/520). According to Bailetti, the ultimate outcomes of technology entrepreneurship are value creation and value capture, and the sources of value creation and value capture may not be the same over the long run. Nonetheless, little is known about the processes by which technology entrepreneurs produce successful business models that both create and capture value. Although 22 of the 93 technology entrepreneurship articles identified by Bailetti examine themes of revenue generation, cost reduction, operations, and business transformation, the specific ways in which technology entrepreneurs discover alternative new approaches for value creation and capture, and the ways in which they select between alternatives, received little attention in these articles. 


\section{Business Model Discovery by Technology Entrepreneurs}

Steven Muegge

This article makes three contributions to the ongoing conversation about business models and technology entrepreneurship, with each contribution presented in its own section. The first section develops and articulates a cogent argument that business model discovery by technology entrepreneurs can be a disciplined process, where discipline refers to both intention, in the sense that opportunities for learning arise through deliberate design, and structure, in the sense that activities are organized as a project work plan to produce specific deliverables. The second section presents a tool for disciplined business model discovery by technology entrepreneurs. The third section shares preliminary results and lessons learned from six technology entrepreneurs applying this tool with their own nascent technology businesses. A final section concludes the article.

\section{Business Model Discovery}

In Seizing the White Space, Mark Johnson (2010; tiny url.com/7a9jcyw) defines a business model as the way in which a company delivers value to a set of customers at a profit. In this view, all firms have a business model, regardless of whether that model is explicit and codified, or implicit in employee behaviours and tacit operating procedures, or at some midpoint along a spectrum between those two poles. Alternative perspectives and definitions of a business model include the story of how a business works, the map linking technological potential to economic outcomes, and the explanation for how a company is expected to make money. Other metaphors include blue print, architecture, logic, and narrative. Table 1 summarizes excerpts from the small but growing research literature on business models.

Many open questions remain. Are business models best understood as broad patterns or archetypes chosen from a finite list, or as something unique that is highly specialized and particular to each firm? Do business models emerge from a discrete choice process or from a continuous process of redesign and discovery? Much depends on the definitions used, but empirical evidence from Chesbrough and Rosenbloom (2002; tinyurl $. c 0 m / 7 \times 2 g 65 \mathrm{~m}$ ) and Chesbrough (2006; tinyurl.com/7qg9szz) favours the latter explanations of business model discovery. According to this body of research: i) the set of all feasible business models is not foreseeable in advance; ii) business models are discovered through search and heuristic logic in a reshaping process; and iii) the reshaping process creates learning opportunities that themselves may contribute importantly to success. This article adopts the discovery perspective.
The definition for technology entrepreneurship (Bailetti, 2012; timreview.ca/article/520) does imply two important differences between the processes of business model discovery of technology entrepreneurs and other types of entrepreneur, both arising from the deep connection between the technology entrepreneurship mechanisms of value creation and value capture and the advancement of science and technology. First, some scientific and technological domains experience rapid change driven by frequent innovations, both incremental and radical. Mobile "smartphone" handsets and application software, cloud computing, and online social media services are three examples of fast-paced domains in which business models must either evolve more quickly or be re-invented more frequently and abruptly than in domains with less technological interdependence or a slower pace of technological change. Second, many technology entrepreneurs have deep roots in engineering, science, and technology. Theory and evidence from organizational psychology suggests that the ways in which individuals frame and define problems and the ways in which they process information to make sense of uncertain situations are all shaped in part by their past experience and domain expertise. For successful scientists and engineers, framing issues as business and management problems rather than technological problems may be an ongoing challenge. Both of these differences are of degree rather than kind, but they do imply that the process of business model discovery for technology entrepreneurs is likely to differ in important ways from that of the "typical" entrepreneur engaging in other forms of entrepreneurship.

Researchers and practitioners have proposed various business model frameworks to operationalize the business model concept. Frameworks explicitly identify an underlying logic, a minimal set of requisite components, and a way to specify each component and its relationships to other components. By establishing a common vocabulary and underlying logic, business model frameworks can advance the dialogue beyond abstractions and narrative stories, and they enable comparison between different firms and of the same firm at different points in time. This article employs a fourfactor framework adapted from multiple sources, including the business model research literature, practitioner articles published the TIM Review (e.g., Bailetti, 2009; timreview.ca/article/226), and the experience of the author and his colleagues from delivering the Lead to Win program (http://leadtowin.ca) and mentoring nascent technology entrepreneurs. The next subsection provides more information on business model frameworks and the particular framework employed for this article. 


\section{Business Model Discovery by Technology Entrepreneurs}

\section{Steven Muegge}

Table 1. Excerpts from the management research literature on business models

\begin{tabular}{|c|c|}
\hline Source & Explanation of what a business model is or does \\
\hline $\begin{array}{l}\text { Amit \& Zott }(2001) \\
\text { tinyurl.com/6r5pv9j }\end{array}$ & $\begin{array}{l}\text { "A business model depicts the content, structure, and governance of transactions } \\
\text { designed so as to create value through the exploitation of business opportunities" } \\
\text { (p. 511). Amit \& Zott emphasizes value creation. }\end{array}$ \\
\hline $\begin{array}{l}\text { Chesbrough \& Rosenbloom } \\
\text { (2002) } \\
\text { tinyurl.com/83d395h }\end{array}$ & $\begin{array}{l}\text { A business model links technological potential to economic outcomes. } \\
\text { The set of all feasible business models is not foreseeable in advance. A business } \\
\text { model is discovered through search and heuristic logic in a reshaping process } \\
\text { creating learning opportunities that themselves may contribute importantly to } \\
\text { success. }\end{array}$ \\
\hline $\begin{array}{l}\text { Magretta }(2002) \\
\text { tinyurl.com/7prxc7c }\end{array}$ & $\begin{array}{l}\text { The business model is a story that explains how the business works. In this view, } \\
\text { the business model is a fluid narrative rather than an operationalized framework. }\end{array}$ \\
\hline $\begin{array}{l}\text { Hedman \& Kalling (2003) } \\
\text { tinyurl.com/86vds8s }\end{array}$ & A business model explains how a venture is expected to make money. \\
\hline \multirow[t]{2}{*}{$\begin{array}{l}\text { Zott \& Amit (2007) } \\
\text { tinyurl.com/7fzqno9 }\end{array}$} & $\begin{array}{l}\text { "A business model elucidates how an organization is linked to external } \\
\text { stakeholders, and how it engages in economic exchanges with them to create } \\
\text { value for all exchange partners" (p. 181). }\end{array}$ \\
\hline & $\begin{array}{l}\text { Two business model design themes are design novelty and design efficiency; both } \\
\text { themes are associated with higher firm performance and can co-exist together. }\end{array}$ \\
\hline $\begin{array}{l}\text { Fiet \& Patel (2008) } \\
\text { tinyurl.com/7r7e7df }\end{array}$ & $\begin{array}{l}\text { A forgiving business model is a business model in which risk is disproportionately } \\
\text { borne by others while venture payoffs and shared proportionately by an } \\
\text { entrepreneur and investors. }\end{array}$ \\
\hline $\begin{array}{l}\text { Zott \& Amit (2008) } \\
\text { tinyurl.com/cydetd8 }\end{array}$ & $\begin{array}{l}\text { "The business model is a structural template of how a focal firm transacts with } \\
\text { customers, partners, and vendors; that is, how it chooses to connect with factor } \\
\text { and product markets. It refers to the overall gestalt of these possibly interlinked } \\
\text { boundary-spanning transactions" (p. 3). }\end{array}$ \\
\hline \multirow[t]{2}{*}{$\begin{array}{l}\text { Bailetti (2009) } \\
\text { timreview.ca/article/226 }\end{array}$} & $\begin{array}{l}\text { Business models and market offers are two sides of the same coin: "For a } \\
\text { company's commercialization efforts to succeed, it needs to come up with great } \\
\text { market offers which have great business models" (p. } 4 \text { ). }\end{array}$ \\
\hline & $\begin{array}{l}\text { Conceptual tools can help capture, share and communicate the strength of a } \\
\text { company's business model and help articulate tacit knowledge into explicit } \\
\text { knowledge. }\end{array}$ \\
\hline $\begin{array}{l}\text { Doganova \& Eyquem-Renault } \\
\text { (2009) } \\
\text { tinyurl.com/crl2aku }\end{array}$ & $\begin{array}{l}\text { "The business model is a narrative and calculative device that allows } \\
\text { entrepreneurs to explore a market and plays a performative role by contributing } \\
\text { to the construction of the techno-economic network of an innovation" (p. 1559). }\end{array}$ \\
\hline $\begin{array}{l}\text { Al-Debei \& Avison (2010) } \\
\text { tinyurl.com/cwgz59u }\end{array}$ & $\begin{array}{l}\text { The "business model" is a popular notion among practitioners, but as a } \\
\text { theoretical construct, there is little consensus among scholars regarding its } \\
\text { operational definition, its compositional facets, or its classification schema. }\end{array}$ \\
\hline $\begin{array}{l}\text { Osterwalder \& Pigneur (2010) } \\
\text { tinyurl.com/d2svk4o }\end{array}$ & $\begin{array}{l}\text { "The business model is like a blueprint for a strategy to be implemented through } \\
\text { organizational structures, processes, and systems" (p. 15). }\end{array}$ \\
\hline $\begin{array}{l}\text { Johnson }(2010) \\
\text { tinyurl.com/ccu6u7p }\end{array}$ & $\begin{array}{l}\text { A business model "defines the way the company delivers value to a set of } \\
\text { customers at a profit" (p. 7). }\end{array}$ \\
\hline $\begin{array}{l}\text { George \& Bock ( } 2011) \\
\text { tinyurl.com/cjkubak }\end{array}$ & $\begin{array}{l}\text { The management research literature variously describes business models as: } \\
\text { i) organizational designs; ii) links between resources and business outcomes; } \\
\text { iii) organizational narratives; iv) opportunities for innovation as well as links } \\
\text { between technological innovation and organization structure; v) transaction } \\
\text { structures; and vi) facilitative intermediaries in the process of moving from } \\
\text { opportunity to value creation. }\end{array}$ \\
\hline
\end{tabular}




\section{Business Model Discovery by Technology Entrepreneurs}

Steven Muegge

\section{Business model frameworks}

Business model frameworks provide a common vocabulary and structure to discuss and compare business models. An ideal business model framework would be intuitively understandable, as simple as possible, and yet retain just enough complexity and nuance to sufficiently capture the operationally and strategically relevant aspects of the business. Many different frameworks have been proposed in the management research literature and the popular business press with no shared consensus on which framework is best, or even which circumstances would favour one framework over another. This article employs a four-factor business model framework intended to specifically address the main concerns of technology entrepreneurs. It is adapted from multiple sources, including three frameworks in the practitioner literature: the "fourbox" framework of Mark Johnson and the Innosight consulting company (seizingthewhitespace.com), the sixfunction framework from Henry Chesbrough's research on open innovation (tinyurl.com/20w32e), and the Business Model Canvas (tinyurl.com/2b6qfcy) of Alexander Osterwalder and Yves Pigneur. It draws also on the business models research literature (e.g., Table 1), practitioner articles in the Open Source Business Resource and TIM Review, and the experience of the author and his colleagues working with early-stage technology entrepreneurs.

The framework has four components. The first component is the importance of the customer "pain point", expressed as an underlying job-to-be-done, a problem-to-be-solved, or an unmet need. Christensen and colleagues (2007; tinyurl.com/6nqm652) argue that a customer perspective on the marketplace, anchored around $a$ job that the customer needs done, is more effective than traditional marketing management that segments around customer demographics and differentiates one offer from competing offers by adding product features and functions. A job that the customer needs done - that pains the customer because that job is not being done - is the starting point and the conceptual bedrock of a strong business model.

The second component is a set of stakeholder value propositions (SVPs). According to Anderson and colleagues (2006; tinyurl.com/6tmrqvv), strong value propositions are based on "points of difference" and "points of parity" with competing solutions. Customers are one important group of stakeholders, but support from other stakeholder groups, each with its own motives and each ap- propriating different stakeholder value, may also be critical to success. Likewise, there may be multiple segments of customers with differing value propositions. This component makes all of that explicit by identifying the critical-to-success stakeholder group and articulating a compelling value proposition for each.

The third component is an explanation of the revenues and costs of delivering on the SVPs, and an explanation of why revenues exceed costs in a way that produces attractive profits. Johnson and colleagues (2010; tinyurl .com/yen7bkz) call this component a profit formula. The metaphor is of a chemical formula rather than a mathematical formula - it is a succinct explanation in words rather than a spreadsheet of sales and expense numbers. The first part of the profit formula identifies the revenue trigger and the stakeholder who pays. In the traditional view of neoclassical economics, the business firm is a merchant-producer that takes inputs from suppliers, transforms those inputs into a product, and sells that product to a customer through a market exchange. Product sales to customers are one possible revenue trigger, but increasingly, many technology entrepreneurship opportunities are more complex. Multi-sided platform opportunities (tinyurl.com/prdzqj) bring together multiple stakeholder groups that each benefit in different ways. For instance, Iyer and Davenport (2008; tiny url.com/3954du2) describe the Google advertising and search platform as bringing together four stakeholder groups: consumers searching for information, content providers with information, advertisers, and innovators of new products and services. Some stakeholders may pay, others may participate for free, and others may need to be paid to contribute. The second part of the profit formula explains the cost structure - where money must be spent to deliver on the SVPs. The third part explains why these revenues and costs will produce attractive profits. In other words, why revenues will exceed costs over the long term to an extent that justifies investment and continued operation. Offering product at a low price is not a sustainable competitive advantage, but a cost structure that allows a company to earn attractive profits at a lower price point can enable a winning business model that competitors cannot imitate.

The fourth component is an explanation of the criticalto-success capabilities needed to deliver on the SVPs while earning attractive profits, and an explanation of how the firm will obtain access to those capabilities or prevent access by rivals. Capabilities can include re- 


\section{Business Model Discovery by Technology Entrepreneurs}

Steven Muegge

sources (assets that the firm needs to obtain) and processes (actions that the firm needs to do). Innovation researchers have long recognized that complementary assets (tinyurl.com/7h7y93e) are often required to profit from technological innovation. Increasingly, technology entrepreneurs can neither own nor exclusively control all of the capabilities needed to create and capture value, and must find novel ways to access these capabilities. Examples include collaborating with others, adopting industry platforms and open standards, nurturing communities of innovation (tinyurl.com/74rne78), and participating in business ecosystems (tinyurl.com/7ohjcqh). This component explicitly identifies the capabilities required and the means by which each of those capabilities will be obtained. The individuals and organizations that provide access to critical capabilities may become critical-to-success stakeholders that require compelling SVPs in the second component of the framework.

Table 2 compares and contrasts this four-factor framework with three other business model frameworks. For technology entrepreneurs, this framework is wellsuited to the complex stakeholder interactions, multisided platform opportunities, distributed innovation, collaboration with other entrepreneurs, and rivalry over complementary assets that are prominent features of many technology-intensive businesses. The tool presented in the next section includes a worksheet for writing down a business model using the four components of this framework. First, however, the next subsection elaborates on the notions of discipline, intent, and structure.

\section{Intent and structure in disciplined business model discovery}

A point of difference between this article and prior work is the emphasis on disciplined business model discovery. Discipline here has two components. The first component is intent, so that opportunities for learning arise through deliberate design and action rather than serendipity or random chance. Technology entrepreneurs can deliberately identify and undertake activities to acquire new information, test assumptions, and uncover new options. The second component is structure, so that discovery-driven activities are organized as project, with beginning and end points in time, specific deliverables, and a work plan to produce those deliverables. Structure does not imply heavyweight upfront planning or inflexibility. Many product development projects maintain tremendous flexibility through frequent iterations and active learning within a lightweight structure; agile software development is a prominent example (Smith, 2007: tinyurl.com/7cqfry2;
Highsmith, 2009: tinyurl.com/7twmkcx). By adopting intent and structure, the process of business model discovery can be managed with comparable discipline to the ways in which entrepreneurs manage costs, product development, and other critical-to-success business activities.

Discipline with respect to intent and structure is the salient difference between the discovery process examined here and the more ad hoc "heuristic" search and shaping process observed in much prior business model research including the descriptive field studies by Chesbrough and his colleagues. Chesbrough (2002; tinyurl.com/733ruxk) examined each of the 35 technologyintensive firms that spun out of Xerox Corporation between 1979 and 1998, and concluded that most of the technologies did not initially have obvious value. Some firms attempted transformations of the technology and business model that resulted in evident value while others did not. Follow-on work by Chesbrough and Rosenbloom (2002; tinyurl.com/7x2g65m) developed detailed case studies on six of these spin-off firms and concluded that significant transformation occurred in the business models of successful spin-offs, while search and learning in failed ventures were quite limited.

In summary, extant research suggests that technology entrepreneurs who can discover and implement stronger business models for their firms are more likely to achieve higher levels of success. Thus improving the process of business model discovery is of high relevance to both research and practice. The next section proposes a tool for business model discovery disciplined by both intention and structure.

\section{A Tool for Disciplined Business Model Discovery}

The tool described here is comprised of two parts: an actionable five-step process (Figure 1) and a worksheet for specifying a business model (Box 1). Box 1 provides a worksheet for writing down the four components of a business model in a form that is at once concise, precise, and explicit. It was developed initially for the Lead to Win entrepreneurship program (leadtowin.ca), then adapted for use within the business model projects of Carleton University's Technology Innovation Management program (TIM; carleton.ca/tim). For each component, the worksheet explains the form that the answer should take, and the limited writing space enforces clarity and parsimony. The research collectively argues that good business models are simply and clearly stated using no more words than necessary to convey a message. 


\section{Business Model Discovery by Technology Entrepreneurs}

\section{Steven Muegge}

Table 2. Comparison of this framework with three other business model frameworks

\begin{tabular}{|c|c|c|c|}
\hline & $\begin{array}{l}\text { "Seizing the Whitespace" } \\
\text { four-box framework }\end{array}$ & $\begin{array}{l}\text { “Open Innovation” } \\
\text { six-function framework }\end{array}$ & "Business model canvas" \\
\hline Parts & $\begin{array}{l}\text { Four boxes: } \\
\text { 1) Customer value proposition } \\
\text { (CVP) } \\
\text { 2) Profit formula } \\
\text { 3) Key resources } \\
\text { 4) Key processes }\end{array}$ & $\begin{array}{l}\text { Six functions: } \\
\text { 1) Articulate the value proposition } \\
\text { for users. } \\
\text { 2) Identify a market segment. } \\
\text { 3) Define the value chain of } \\
\text { suppliers and customers. } \\
\text { 4) Specify the revenue generation } \\
\text { mechanism and estimate the cost } \\
\text { structure and profit potential. } \\
\text { 5) Position the firm within a value } \\
\text { network, including complementors } \\
\text { and competitors. } \\
\text { 6) Formulate the competitive } \\
\text { strategy to gain and hold advantage } \\
\text { over rivals. }\end{array}$ & $\begin{array}{l}\text { Nine basic building blocks: } \\
\text { 1) Customer segments (CS). } \\
\text { 2) Value propositions (VP). } \\
\text { 3) Channels (CH). } \\
\text { 4) Customer relationships (CR). } \\
\text { 5) Revenue streams (R\$). } \\
\text { 6) Key resources (KR). } \\
\text { 7) Key activities (KA). } \\
\text { 8) Key partnerships (KP). } \\
\text { 9) Cost structure (C\$). }\end{array}$ \\
\hline $\begin{array}{l}\text { How this } \\
\text { framework } \\
\text { is similar }\end{array}$ & $\begin{array}{l}\text { - Direct mapping from the four } \\
\text { boxes: } \\
\text { - Stakeholder value } \\
\text { propositions (SVPs) include } \\
\text { the CVP. } \\
\text { - } \quad \text { Profit formula includes } \\
\text { revenue, costs and profit. } \\
\text { - Capabilities include } \\
\text { resources and processes. } \\
\text { - Parsimony. } \\
\text { - Small number of parts. } \\
\text { - Parts build on previous parts. }\end{array}$ & $\begin{array}{l}\text { - Partial mapping from the six } \\
\text { functions: } \\
\text { - SVPs include the value } \\
\text { proposition and market } \\
\text { segment, and may include } \\
\text { complementors. } \\
\text { - Profit formula includes } \\
\text { revenue, costs and profit. } \\
\text { - Capabilities may include } \\
\text { aspects of the value chain and } \\
\text { value network. }\end{array}$ & $\begin{array}{l}\text { - Direct mapping from the nine } \\
\text { building blocks: } \\
\text { - SVPs include the CS and VP } \\
\text { blocks, and aspects of the } \mathrm{CH} \\
\text { and CR blocks. } \\
\text { - Profit formula includes the R\$ } \\
\text { and C } \$ \text { blocks. } \\
\text { - Capabilities include the KR } \\
\text { and KA blocks and aspects of } \\
\text { the CH, CR and KP blocks. }\end{array}$ \\
\hline $\begin{array}{l}\text { How this } \\
\text { framework } \\
\text { is different. }\end{array}$ & $\begin{array}{l}\text { - Importance of the problem is } \\
\text { explicit rather than folded into } \\
\text { the value proposition. } \\
\text { - Requires value propositions for } \\
\text { each stakeholder group (SVPs) } \\
\text { rather than a single customer } \\
\text { value proposition (CVP) that } \\
\text { combines the problem and offer. } \\
\text { - The capabilities component } \\
\text { includes both resources and } \\
\text { processes, and makes explicit } \\
\text { how the business will secure } \\
\text { access to each. }\end{array}$ & $\begin{array}{l}\text { - Requires value propositions for } \\
\text { each stakeholder group (SVPs) } \\
\text { rather than a single value } \\
\text { proposition for users. } \\
\text { - The capabilities component } \\
\text { makes explicit how the business } \\
\text { will secure access to key } \\
\text { capabilities; emphasis is different } \\
\text { from value chain and value } \\
\text { network which emphasize } \\
\text { relationships. } \\
\text { - Does not directly address } \\
\text { competitive strategy (implicit in } \\
\text { SVPs and profit formula). }\end{array}$ & $\begin{array}{l}\text { - Importance of the problem is } \\
\text { explicit. } \\
\text { - Less granular; fewer parts. } \\
\text { - Requires value propositions for } \\
\text { each stakeholder group (SVPs) } \\
\text { rather than treating customers } \\
\text { and other stakeholders } \\
\text { separately. } \\
\text { - The capabilities component } \\
\text { encompasses five business model } \\
\text { canvas building blocks. This } \\
\text { framework is simpler, but } \\
\text { requires more judgment to } \\
\text { employ well. }\end{array}$ \\
\hline
\end{tabular}




\section{Business Model Discovery by Technology Entrepreneurs}

Steven Muegge

Box 1. Worksheet for specifying a business model

\section{Importance (pain point)}

Explain why the job-to-be-done, problem, or unmet need matters to stakeholders.

\section{Stakeholder Value Propositions}

Explain the value for each critical stakeholder.

We have\# critical stakeholders. To stakeholder \#1, we provide... . To stakeholder \#2, we create.......

\section{Profit Formula}

Explain how the business produces attractive profits.

Our revenues are .... Our costs are .... Other attributes critical to our business are ... .

Our revenues are greater than our costs because ....

\section{Capabilities (resources and processes)}

Explain how the business obtains access to key resources and processes.

We need access to these key resources and processes. (Explain how you secure access to each capability, collaborate for capabilities

that you neither own nor control, and protect your own unique intellectual property). 


\section{Business Model Discovery by Technology Entrepreneurs}

\section{Steven Muegge}

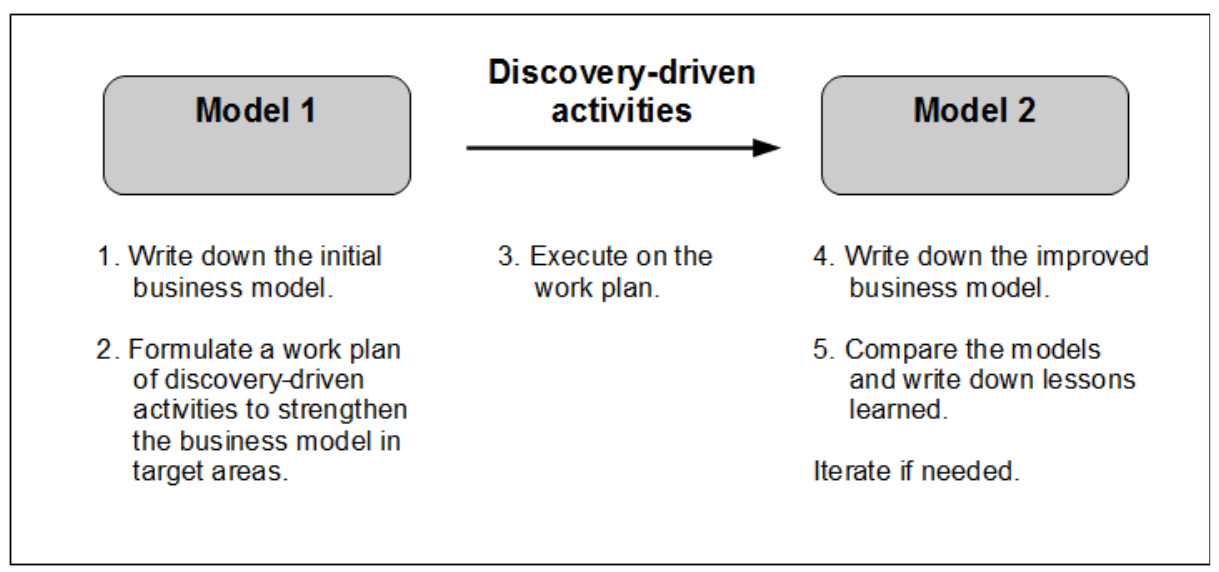

Figure 1. A disciplined five-step process for business model discovery

The five prescriptive steps of the process are as follows.

Step 1. Write down the initial business model. For clarity, we label this "Model 1" and explain how the business works using the four-part business model framework described earlier and the worksheet of Box 1. The intent at this step is making explicit what is known and unknown about how the business works. The initial business model may be complete, with clear explanations for each part, or it may be incomplete, with gaps and unknowns, guesses and unsupported assumptions, or enumerated lists of possibilities with no clear decision rule or winner - either case is fine. If the best explanation at this time is "I don't know how to price my offer" or "We have identified three jobs-to-bedone by the customer, but we haven't decided which to address first", that is what you write down.

Step 2. Identify specific target areas to improve, identify a set of discovery-driven activities to strengthen the business model in the target areas, and develop a work plan for implementation. This step groups together several interconnected tasks that collectively form a plan of action and make that plan explicit. First, candidly assess the strengths and weaknesses of Model 1 to identify the areas most needing improvement. Assessment tools may sometimes be helpful, such as the tool for assessing business model strength published in the February 2009 issue of the OSBR (Bailetti, 2009; timreview.ca/article/226). Based on your objectives, the context, and the results of your assessment, select one or more target areas of the business model to deliberately strengthen. Depending on the completeness of the initial business model, im- proving target areas may require generating new options, collecting information and reducing uncertainty, or selecting among a list of known options. Because each part of the framework builds on and depends on previous parts, it may make sense to work on strengthening earlier parts before proceeding to later parts. Next, identify a set of activities to deliberately strengthen the target areas. Examples of possible discovery-driven activities include direct interaction with stakeholders (e.g., interviews or focus groups), collection and analysis of publicly available information (e.g., competitive analysis), structured data collection (e.g., a large sample questionnaire), multiple parallel market experiments, and development of concept prototypes or beta products. Finally, structure these activities into a project work plan, with a distinct beginning and end point, and a clear set of specific, measurable, and actionable deliverables. The work plan should explicitly include activities to collect missing information and analysis activities to process and learn from that information after it is available. Be diligent about writing everything down - you will need this information later.

Step 3. Execute on the work plan. Complete the discovery-driven activities to produce the deliverables. The plan of action developed in step 2 may change in response to new information or to take advantage of opportunities discovered while executing on the plan.

Step 4. Write down the new business model. For clarity and consistency with previous steps, we label this "Model 2" and employ the same business model framework and worksheet format as in step 1. 


\section{Business Model Discovery by Technology Entrepreneurs}

Steven Muegge

Step 5. Compare the two business models and clearly articulate lessons learned. Review your notes from previous steps and try to clearly articulate i) how Model 2 is different from Model 1; ii) what was learned between Model 2 and Model 1; and iii) what actions would need to be undertaken to implement Model 2. As with each prior step, continue keeping comprehensive written notes. Accurate and extensive notes of steps 1 through step 4 are needed to complete step 5 . These five steps can be iterated again to discover "Model 3", or enfolded into an ongoing continuous improvement process to discover "Model $\mathrm{n}+1$ ", and good notes about step 5 may be valuable in future iterations.

Also important is candidly assessing whether Model 2 is, in fact, an improvement over Model 1 or is merely different. The ultimate test of a business model is whether or not it makes money over time by both creating and capturing value. Without a field trial to actually implement the new business model, there are at least three complementary, evidence-based approaches to assessing improvement. A first approach is weight of evidence. For example: "I have now spoken with XXX customers in YYY categories about value propositions and willingness to pay; previously I had spoken only to ZZZ users in the same category" or "I ran four experiments, and scenario 3 had better measurable results than the others, including the scenario of my initial business model." An entrepreneur who can make statements like these may have higher confidence in Model 2 than in Model 1 due to the accumulating weight of evidence. A second approach is increased knowledge and reduced uncertainty. List the "unknowns" for Model 1 and Model 2 and determine whether the second list is shorter than the first list. Some subjectivity and interpretation is required here in assessing knowledge and uncertainty. For example, the discovery-driven activities of business model discovery may actually uncover "unknowns" that were not previously recognized in the list for Model 1. If so, the list of "unknowns" might actually become longer. In the sometimes awkward language of decision theory, overall uncertainty could be reduced by transforming "unknown unknowns" into "known unknowns" that can be further investigated. Alternatively, or in addition, you could list what is known about each model and determine whether the second list is longer than the first. A third approach is measurement with an assessment tool. For example, you could apply the business model assessment tool from the February 2009 OSBR (Bailetti, 2009; timreview.ca/article/226) on both Model 1 and Model 2 and compare the numerical results. None of these approaches are ideal replace- ments for a field trial, but each provides some information, and they may complement one another in combination.

This process of disciplined business discovery was developed initially for graduate engineering and computer science students completing applied research in Carleton University's Technology Innovation Management (TIM; carleton.ca/tim) program, however nothing about the process restricts its application to that context. Box 2 provides more information about the TIM program and the role of applied research in the TIM degree requirements. The next section presents preliminary results of applying the process by entrepreneurs in the TIM program.

\section{Applying the Process and Worksheet}

Table 3 presents summary results of six projects of disciplined business model discovery undertaken by six technology entrepreneurs. Some of these entrepreneurs had successful companies that they wanted to grow to the next stage, either by scaling what they had or by transforming their business into something very different. Some were in the early days of launching their first company and sought to grow from the first paying customer to the sustainable revenues that could bootstrap further growth. One was making a decision whether or not to enter a new market and sought to assess whether or not there was a viable business model in this new space. All six entrepreneurs were also graduate students in Carleton University's TIM program and I was the faculty supervisor for each of their applied research projects. In that capacity, I worked with each entrepreneur to clearly specify the objective, deliverables, relevance, and contribution of their applied research

Box 2. Graduate studies in technology innovation management

Technology Innovation Management (TIM; carleton .ca/tim) is a research-based graduate program at Carleton University in Ottawa, Canada. One option for graduate students earning a Master of Engineering degree is to complete an applied research project that solves a problem for a client company. Some TIM graduate students are entrepreneurs with their own companies and some of these students become their own clients and undertake applied research to strengthen their company's business model. 


\section{Business Model Discovery by Technology Entrepreneurs}

Steven Muegge

and a viable work plan to produce the deliverables, advised them on data collection, analysis, and interpreting their results, and helped them clearly communicate what they did and what they learned as a concise project report. Individually, each project discovered a business model to exploit a business opportunity. Collectively, this set of projects contributes to an ongoing research program on the business models and strategic decisions of technology entrepreneurs.

Each technology entrepreneur completed the five-step process outlined in the previous section. The details of each business model are the intellectual property of the entrepreneurs, so only summary information is reported here. The projects varied widely in the completeness of their initial business models: some began with all four parts of the framework fully specified, while others began with large gaps, unknowns, and lists of possible alternatives. The projects also varied widely in the areas targeted for improvement: most focused on improving two areas of the business model framework, but the target areas collectively spanned the entire fourpart framework. The work undertaken to improve the business models likewise varied, with discovery-driven activities including loosely-structured interviews with potential customers, a structured online survey of a customer segment, a "lead user" study of individuals whose needs are far ahead of the mainstream market, analysis of competitor pricing and business models, and the construction of concept prototypes and earlystage "alpha" products. One project was completed in December 2011, four projects are in their late stages with completion expected in April 2012, and one earlystage project expects to complete in August 2012.

The lessons learned from these projects varied widely. Two entrepreneurs refocused their business models on different customer problems: the first discovered an adjacent problem that was more lucrative than the original focus and the second discovered that the initial target problem was actually several closely related problems with interdependencies, complementarities, and economies of scope. Another entrepreneur discovered new revenue opportunities through technology licensing that could supplement their revenue stream of product sales. Two entrepreneurs redefined the ways in which they were segmenting stakeholders, resulting in sharper and more compelling value propositions. Three entrepreneurs learned about the buying behaviour of customers, which allowed them to improve their profit formulas. Two entrepreneurs developed requirement specifications for the minimum viable product demanded by their target customers and developed plans to acquire that functionality.

\section{Conclusion}

This article has examined the process of business model discovery by technology entrepreneurs. It has argued for the efficacy of a disciplined approach, provided a tool comprised of an actionable five-step process and a business model worksheet, and presented preliminary results and lessons learned from application of the tool by six technology entrepreneurs with nascent technology businesses. All projects examined here employed a four-factor business model framework described in this article, but nothing precludes an entrepreneur from employing a disciplined discovery process using a different business model framework. Likewise, all projects examined here were conducted as applied research projects within Carleton University's TIM program, but nothing precludes others seeking to exploit a business opportunity from employing a disciplined discovery process in other settings. The key points advocated here are intent to learn quickly through deliberate action, and a structure similar to the way in which engineers and scientists approach product development and other critical business functions. Although preliminary, these early field results provide some empirical support for the argument that discipline of intent and structure can help technology entrepreneurs think more clearly about their businesses and channel effort into discovery-driven activities more likely to achieve desired outcomes.

\section{Acknowledgments}

The author thanks the six entrepreneurs who agreed to share their stories and preliminary research results, and who provided helpful advice on improving early drafts of this article: John Schreuders, Natasha D'Souza, Samer Abu-Saifan, Elias Majic, James Makienko, and Robert Poole. Best wishes for continued success. Thanks also to my colleagues in the TIM program and Lead to Win program - faculty, graduate students, and aspiring entrepreneurs - for the hours debating, strengthening, sharpening, and refining these ideas, and for your enthusiasm and energy at applying them in practice. 


\section{Business Model Discovery by Technology Entrepreneurs}

\section{Steven Muegge}

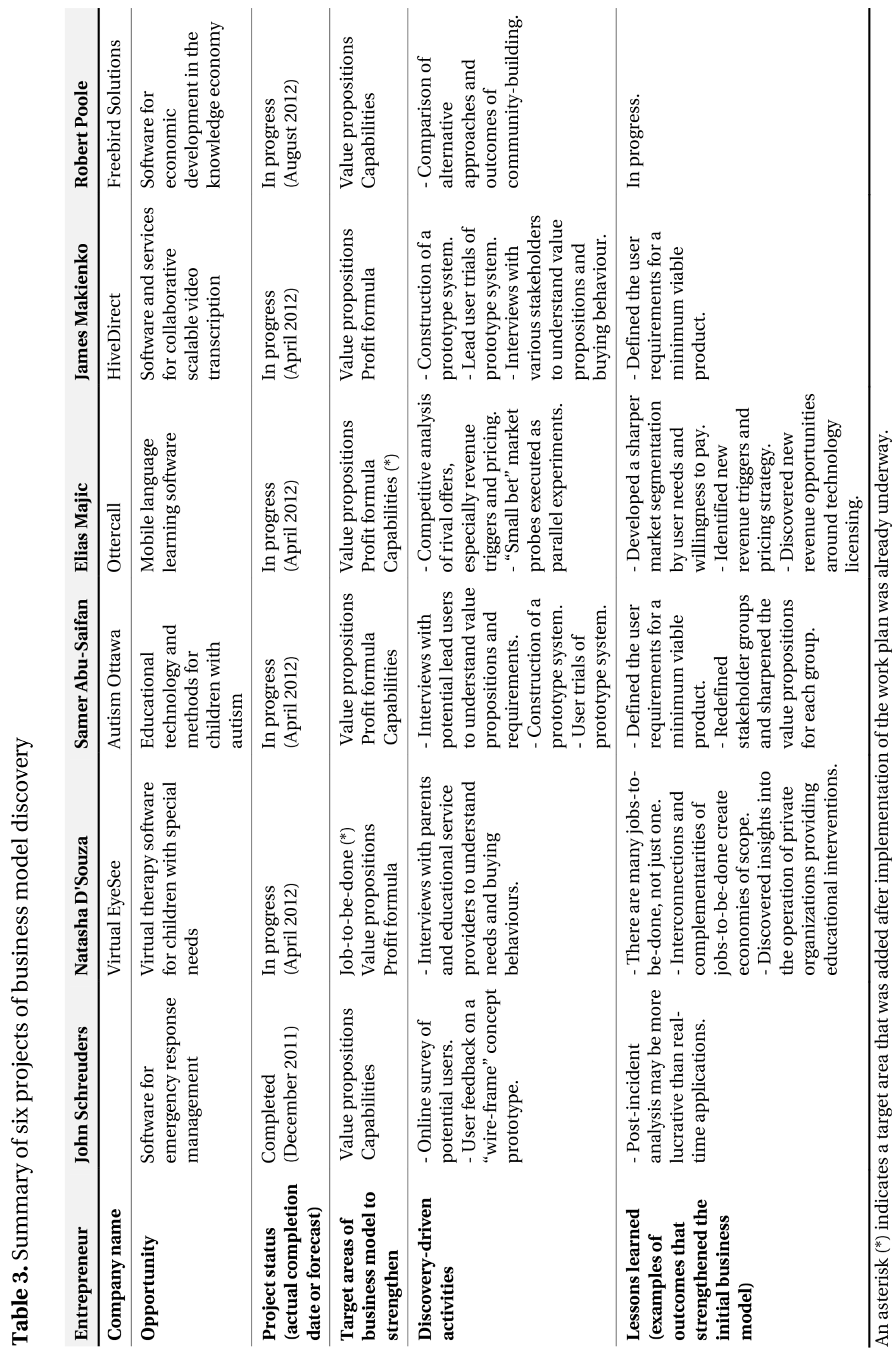




\section{Business Model Discovery by Technology Entrepreneurs}

Steven Muegge

\section{Recommended Reading}

The author maintains a website of business model research and practitioner resources:

- steven.muegge.net/business-models

The following three books each provide further background on the development and application of one of the alternative business model frameworks of Table 2 .

1. Johnson, M.W. 2010. Seizing the White Space: Business Model Innovation for Growth and Renewal.

- Book: tinyurl.com/ccu6u7p

-Website for the book: seizingthewhitespace.com

2. Chesbrough, H.W. 2006. Open Business Models: How to Thrive in the New Innovation Landscape.

- Book: tinyurl.com/8y5gp7s

- Website for the open innovation community: openinnovation.net

3. Osterwalder, A. \& Pigneur, Y. 2010. Business Model Generation.

- Book: tinyurl.com/7t2gu33

-Website for the book: businessmodelgeneration.com

\section{Additional Resources}

A printable version of the business model worksheet in Box 1 can be found at: timreview.ca/article/545

\section{About the Author}

Steven Muegge is an Assistant Professor at the Sprott School of Business at Carleton University in Ottawa, Canada, where he teaches within the Technology Innovation Management (TIM) program. His research interests include open and distributed innovation, technology entrepreneurship, product development, and commercialization of technological innovation. The ideas presented in this article were an outcome of work with talented graduate students in the TIM program, mentoring first-time entrepreneurs in the Lead to Win (http://leadtowin.ca), Ottawa Young Entrepreneurs (OYE), and Carleton Entrepreneurs programs, and his own research program on commercializing innovation.

Citation: Muegge, S. 2012. Business Model Discovery by Technology Entrepreneurs. Technology Innovation

(cc) BY 